Published in final edited form as:

J Matern Fetal Neonatal Med. 2015 ; 28(15): 1833-1838. doi:10.3109/14767058.2014.969236.

\title{
Cystatin $\mathbf{C}$ in newborns: a promising renal biomarker in search for standardization and validation
}

\author{
Karel Allegaert ${ }^{1,2}$, Djalila Mekahli ${ }^{2,3}$, and John van den Anker ${ }^{4,5,6}$
}

${ }^{1}$ Neonatal Intensive Care Unit, University Hospitals Leuven, Leuven, Belgium ${ }^{2}$ Department of Development and Regeneration, KU Leuven, Belgium ${ }^{3}$ Department of Pediatric Nephrology, University Hospitals Leuven, Leuven, Belgium ${ }^{4}$ Departments of Pediatrics, Pharmacology, Physiology and Integrative Systems Biology, George Washington University School of Medicine and Health Sciences, WA, USA 5 Intensive Care, Erasmus MC-Sophia Children's Hospital,

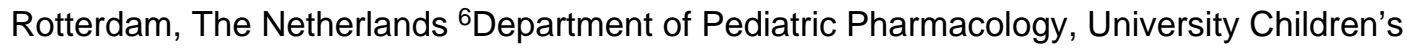
Hospital Basel, Switzerland

\section{Abstract}

Objective-Neonatologists still commonly use creatinine as a proxy for renal clearance, despite issues related to neonatal (patho)physiology and methodology (assay variability). Cystatin C (CysC) has been suggested to be a more reliable biomarker, but assay related differences have also been reported in children and adults. We are unaware of any review on the assay related impact on CysC reference values in newborns.

Methods-A structured literature search was performed on published CysC values in (pre)term neonates.

Results-The extensive range ( $>5$-fold) in serum CysC observations in neonates in part relates to the fact that $\mathrm{Cys} \mathrm{C}$ concentrations are higher at birth with subsequent decrease and that $\mathrm{CysC}$ concentrations are higher in preterm compared to term neonates. The $\mathrm{Cys} C$ assay matters while disease characteristics also affect $\mathrm{Cys} C$ values, but not always in the predicted direction.

Conclusions-Similar to creatinine, the extensive CysC range in neonates is only in part explained by renal (patho)physiology. Its applicability in neonatal medicine can be further improved by use of assay specific reference values, adapted to neonatal renal physiology (e.g. weight, age) and should be compared to a gold standard such as inulin clearance.

\section{Keywords}

Cystatin C; developmental nephrology; neonatal renal clearance; glomerular filtration rate

\footnotetext{
Address for correspondence: Karel Allegaert, MD PhD, Neonatal Intensive Care Unit, University Hospital, Herestraat 49, 3000 Leuven, Belgium. Tel: +00-32-16-343850. Fax: +00-32-16-343211. karel.allegaert@uzleuven.be.

Declaration of interest

None of the authors has to declare any conflict of interest related to the topic discussed in this paper.
} 


\section{Introduction}

Glomerular filtration rate (GFR) in early life is very low and can only be maintained due to a delicate balance between both vasodilatory effects at the afferent arterioli (e.g. prostaglandins) as well as vasoconstrictive effects at the efferent glomerular arterioli (e.g. angiotensin II). Despite this low clearance capacity, the GFR variability within this population is extensive (at least 5 -fold) and can in part be predicted by covariates like e.g. gestational age, birth weight, postnatal age, drugs, growth restriction or peripartal asphyxia, but also assay (Jaffe or enzymatic) related differences [1-7]. Despite this variability, GFR is a relevant parameter, since renal dysfunction is associated with increased mortality and morbidity (e.g. retinopathy of prematurity, neurodevelopmental impairment) in neonates, and is crucial to tailor pharmacotherapy or fluid exposure to the individual newborn [1-7]. Furthermore, an association of extreme preterm birth and renal dysfunction in later life has been described [1,7].

At present, serum creatinine is commonly measured as a proxy for renal (dys)function. However, before creatinine values can be used to estimate renal elimination capacity, there are some specific aspects related to (patho)physiology and bio-analysis that need to be considered. Creatinine at birth does not yet reflect neonatal but maternal creatinine [1,8]. Moreover, because of passive tubular back leak instead of active secretion, creatinine clearance does not yet fully reflects GFR. Finally, creatinine values also depend on the technique (Jaffe or enzymatic assays) used for its measurement [1,6,7]. The move towards harmonization through isotope dilution mass spectrometry (IDMS) traceability helped to reduce the extent of the between assay differences, but has not fully abolished the problem $[1,9,10]$.

Low molecular weight proteins (e.g. Cystatin C, beta-trace protein, beta-2 microglobulin, alfa-1 microglobulin) have been suggested to be more reliable biomarkers [11-13] to estimate renal elimination capacity and - related to this - risk assessment based on kidney function in adult patients [14]. It is hereby has been assumed that Cystatin C (CysC) is not affected by gender, body muscle mass, age, inflammation or nutritional conditions [14,15] although these assumptions and claims are not yet sufficiently supported by data in early infancy [7].

CysC is a low-molecular mass $(13 \mathrm{kDa})$ basic protein and belongs to the cystatin superfamily of reversible inhibitors of cysteine proteases. It is a proteinase inhibitor involved in normal intracellular protein turnover. Consequently, Cys C is produced at a constant rate by any nucleated cell, and is eliminated exclusively through glomerular filtration. After ultrafiltration through the glomerular basal membrane, CysC is metabolized in the proximal renal tubular cell following endocytosis at the apical brush border of the renal tubular cell $[7,9,13]$. Consequently, serum CysC reflects GFR, while urinary CysC reflects renal tubular dysfunction.

Unfortunately, before $\mathrm{CysC}$ can be considered to be a good biomarker for renal elimination capacity in newborns, similar aspects as related to creatinine should be considered. An important advantage is that - as compared to creatinine - $\mathrm{CysC}$ does not cross the placental 
barrier [16]. Consequently and in contrast to creatinine, there is no correlation between maternal and umbilical cord blood CysC observations $[8,16]$. However, the daily caloric needs and metabolic activity are significantly different in early infancy while renal tubular cell transport activity also displays extensive maturation. This may affect $\mathrm{Cys} C$ production or CysC elimination respectively. Finally and comparable to creatinine, there are different methods reported to quantify CysC with suboptimal diagnostic performance because of imprecision, between assay differences, over-recovery or between laboratory differences $[17,18]$. Until now, this assay related issue remained unexplored in this specific population.

At present, there are at least three different registered methods for serum CysC analysis. Besides particle-enhanced nephelometric immune-assays (PENIA), the use of particleenhanced turbimetric immune-assays (PETIA) and enzyme-linked immune-assays (ELISA) methods have been reported and paired analysis confirmed between assay differences [17]. For both PENIA and PETIA, specific GFR equations have been developed in adults and children $[9,13,18]$. This resulted in the suggestion of $\mathrm{Li}$ et al. to apply assay-specific cystatin $\mathrm{C}$ based GFR equations or estimators, until an international calibration for $\mathrm{CysC}-$ similar to the above mentioned IDMS approach for creatinine - has been developed [18]. Since we are unaware of any review on assay-specific relevance of CysC reference values in newborns, we performed an extensive literature search to collect information on $\mathrm{CysC}$ reference values and its covariates in neonates.

\section{Methods}

An electronic bibliographic search was performed, using PubMed and EMBASE as search engines. Keywords were "infant", "newborn" or "preterm" and "Cystatin C" with a cut-off point in time (August 2014). Retrieved sources were further explored applying both the snowball approach (verifying the references) as well as verifying for citations of these original papers through Isi-knowledge and PubMed. Corresponding authors were contacted for additional information on assay related issues if this was not sufficiently clearly described in the original source document.

CysC reference values were extracted from these source documents based on mean and standard deviation, median and range or reference value as published by the authors and were classified based on the clinical characteristics [healthy term (Table 1), healthy preterm (Table 2), specific disease characteristics (Table 3)] with explicit reference to the assay used to quantify CysC.

\section{Results}

Based on the bibliographic search, data in 13 cohorts of healthy term cases (1549 CysC measurements, day 1-30, Table 1) [16,19-30] and in 12 cohorts of healthy preterm cases (1 519 CysC measurements, day 1-30, gestational age 24-36 weeks, Table 2) [24,28,30,32-37] were retrieved. In search for specific disease characteristics, we retrieved information on the impact of gentamicin exposure, peripartal asphyxia, umbilical cord $\mathrm{pH}$, congenital renal anomalies, renal dysfunction, respiratory distress with or without acute kidney injury, and sepsis/severe sepsis/septic shock on CysC measurements (Table 3) [25,29,30,33,36,38,39]. 
Cohorts were reported chronologically. Pooled CysC measurements in preterm and term cases, or in neonates and young infants were not retained in these tables.

\section{Discussion: how to aim for a moving target?}

The quality of neonatal care depends on the availability of reference intervals for any specific laboratory test or biomarker to support prognosis, clinical decision making or to tailor therapy $[7,40,41]$. Since maturational variability is most prominent in early infancy, the crucial issue is how to disentangle the signal from the noise, as illustrated in the extensive variability in CysC reference values. This variability in part is due to physiological changes (e.g. gestational or postnatal age, weight) (Tables 1 and 2) as well as changes related to pathophysiology (e.g. peripartal asphyxia, co-medication, haemoglobin, respiratory distress) (Table 3). Besides these (patho)physiogical covariates, we also found arguments on the relevance of assay differences in newborns to explain the range in CysC values reported.

In essence, (i) CysC concentrations are higher at birth, with a subsequent decrease in term as well as preterm neonates, (ii) $\mathrm{Cys} C$ concentrations are higher in preterm neonates when compared to term neonates, with the highest values in the most immature cases, (iii) $\mathrm{CysC}$ assays also matter for neonates. Even if we limit the analysis to blood samples in healthy term neonates in the first $24 \mathrm{~h}$ of life to restrict the impact of covariates, there is significant difference in mean values reported following PETIA [16,19,20] or ELISA [26] compared to PENIA assays [21,23,27,28,30], as illustrated in Figure 1. Finally, (iv) disease characteristics like respiratory distress [36], bilateral kidney abnormalities [25], peripartal asphyxia [30,38], aminoglycoside exposure [29], hemoglobin [30,38], renal dysfunction [33,37] or sepsis [39] also affect the CysC values observed, but not always in the expected direction. Aminoglycoside exposure in preterm neonates resulted in slightly lower serum CysC values, suggesting higher clearance [29]. Similar, neonates in septic shock had lower CysC values when compared to neonates with (severe) sepsis [39]. This strongly suggests that besides aspects related to the $\mathrm{CysC}$ assay, additional clinical research is needed to document the potential add on benefit of more advanced biomarkers like $\mathrm{Cys} C$ in neonatal medicine.

Different authors described a progressive physiological decrease in CysC values throughout infancy, with subsequent stabilization to age-independent reference values after the first year of life $(0.57-1.12 \mathrm{mg} / \mathrm{l})[1,9,13,20,21,31]$. This means that - similar to creatinine - agespecific reference values in early infancy are needed before we can consider to integrate this biomarker into neonatal practice as a sensitive and specific marker to discriminate between physiology and pathophysiology (i.c. renal dysfunction) [7,40,41]. Moreover, CysC values should be compared to golden standard clearance assessment tools [e.g. inulin clearance, ${ }^{51}$ Chrome ethylene diamine tetra acetic acid (EDTA), ${ }^{99} \mathrm{~m}$ Technecium diethylene triamine penta acetic acid (DTPA)] to confirm that CysC values can be converted to GFR estimates. At present, we are only aware of one study in 20 preterm infants that linked CysC values to inuline clearance $($ correlation $=0.766)($ Table 3$)$ [33]. 
Based on the currently retrieved information, an extensive range (5-fold) in serum CysC observations in early infancy has been documented, only in part explained by renal (patho)physiology. This can be further improved by the use of assay specific reference values. Such reference values should be adapted to the clinical characteristics (e.g. weight, gestational or postnatal age) and compared to inulin clearance or similar as golden standard for GFR estimation. Besides the search for new biomarkers, we feel strongly that the efforts made to standardize creatinine assays toward IDMS also hold an unique opportunity to develop serum creatinine reference values and centiles for creatinine in (pre)term neonates $[6,7,40,41]$. A research effort similar to the CALIPER (Canadian Laboratory Initiative on Pediatric Reference intervals) initiative, but focussed on early infancy reference values is mandatory $[7,15,40,41]$ to really disentangle the signal from the noise.

\section{Acknowledgments}

Karel Allegaert is supported by the Fund for Scientific Research, Flanders (Fundamental Clinical Investigatorship $1800214 \mathrm{~N}$ ) and by an IWT-SBO project (130033). Djalila Mekahli is supported by the Fund for Scientific Research, Flanders (Clinical Fellowship 1700613N) and a research grant of the University Hospitals (postdoctoral mandate). Johannes van den Anker is supported by NIH grants (R01HD048689, K24DA027992, U54HD071601) and FP7 grants TINN (223614), TINN2 (260908) and GRIP (261060).

\section{References}

1. Guignard, JP.; Gouyon, JB. Glomerular filtration rate in neonates. In: Oh, W.; Guignard, JP.; Baumgart, S., editors. Nephrology and fluid/electrolyte physiology; Neonatology Questions and Controversies. 1st. Philadelphia: Saunders Elsevier; 2008.

2. Bueva A, Guignard JP. Renal function in preterm neonates. Pediatr Res. 2004; 36:572-577. [PubMed: 7877873]

3. Rhodin MM, Anderson BJ, Peters AM, et al. Human renal function maturation: a quantitative description using weight and postmenstrual age. Pediatr Nephrol. 2009; 24:67-76. [PubMed: 18846389]

4. Van den Anker JN, de Groot R, Broerse HM, et al. Assessment of glomerular filtration rate in preterm infants by serum creatinine: comparison with inulin clearance. Pediatrics. 1995; 96:11561158. [PubMed: 7491242]

5. Allegaert K, Anderson BJ, van den Anker JN, et al. Renal drug clearance in preterm neonates: relation to prenatal growth. Ther Drug Monit. 2007; 29:284-291. [PubMed: 17529884]

6. Allegaert K, Kuppens M, Mekahli D, et al. Creatinine reference values in ELBW infants: impact of quantification by Jaffe or enzymatic method. J Matern Fetal Neonatal Med. 2012; 25:1678-1681. [PubMed: 22273037]

7. Mussap M, Fanos V. Neonatal nephrology and laboratory medicine: an effective interdisciplinary model to improve the outcome in neonatal intensive care unit. J Matern Fetal Neonatal Med. 2011; 24:1-2. [PubMed: 21801120]

8. Kuppens M, George I, Lewi L, et al. Creatinaemia at birth is equal to maternal creatinaemia at delivery: does this paradigm still hold? J Matern Fetal Neonatal Med. 2012; 25:978-980. [PubMed: 21867404]

9. Delanaye P, Ebert N. Assessment of kidney function: estimating GFR in children. Nat Rev Nephrol. 2012; 8:503-504. [PubMed: 22825669]

10. Allegaert K, Pauwels S, Smits A, et al. Enzymatic isotope dilution mass spectrometry (IDMS) traceable serum creatinine is preferable over Jaffe in neonates and young infants. Clin Chem Lab Med. 2014; 52:e107-e109. [PubMed: 24399679]

11. Zaffanello M, Antonucci R, Cuzzolin L, et al. Early diagnosis of acute kidney injury with urinary biomarkers in the newborn. J Matern Fetal Neonatal Med. 2009; 22:62-66. [PubMed: 19718591] 
12. Zwiers AJ, Cransberg K, de Rijke YB, et al. Reference ranges for serum $\beta$-trace protein in neonates and children younger than 1 year of age. Clin Chem Lab Med. 2014 [Epub ahead of print].

13. Levey AS, Inker LA, Coresh J. GFR estimation: from physiology to public health. Am J Kidney Dis. 2014; 63:820-834. [PubMed: 24485147]

14. Shlipak MG, Matsushita K, Ärnlöv J, et al. Cystatin C versus creatinine in determining risk based on kidney function. N Engl J Med. 2013; 369:932-943. [PubMed: 24004120]

15. Filler G, Lepage N. Cystatin C adaptation in the first month of life. Pediatr Nephrol. 2013; 28:991994. [PubMed: 23436176]

16. Cataldi L, Mussap M, Bertelli L, et al. Cystatin C in healthy women at term pregnancy and in their infant newborns: relationship between maternal and neonatal serum levels and reference values. Am J Perinatol. 1999; 16:287-295. [PubMed: 10586982]

17. Hossain MA, Emara M, El Moselhi H, et al. Comparing measures of cystatin C in human sera by three methods. Am J Nephrol. 2009; 29:381-391. [PubMed: 18974639]

18. Li J, Dunn W, Breaud A, et al. Analytical performance of 4 automated assays for measurement of cystatin C. Clin Chem. 2010; 56:1336-1339. [PubMed: 20562350]

19. Plebani M, Mussap P, Bertelli L, et al. Determination of blood cystatin in pregnant women during labor and in their newborns. Pediatr Med Chir. 1997; 19:325-329. [PubMed: 9493223]

20. Bökenkamp A, Domanetski M, Zinck R, et al. Reference values for cystatin C serum concentrations in children. Pediatr Nephrol. 1988; 12:125-129. [PubMed: 9543370]

21. Harmoinen A, Ylinen E, Ala-Houhala M, et al. Reference intervals for cystatin C in pre- and fullterm infants and children. Pediatr Nephrol. 2000; 15:105-118. [PubMed: 11095024]

22. Bahar A, Yilmaz Y, Unver S, et al. Reference values of umbilical cord and third-day cystatin C levels for determining glomerular filtration rates in newborns. J Int Med Res. 2003; 31:231-235. [PubMed: 12870377]

23. Bariciak E, Yasin A, Harrold J, et al. Preliminary reference intervals for cystatin C and beta-trace protein in preterm and term neonates. Clin Biochem. 2011; 44:1156-1159. [PubMed: 21771588]

24. Novo AC, Sadeck Lso S, Okay TS, et al. Longitudinal study of cystatin C in healthy term newborns. Clinics. 2011; 66:217-220. [PubMed: 21484036]

25. Parvex $\mathrm{P}$, Combescure $\mathrm{C}$, Rodriguez $\mathrm{M}$, et al. Is cystatin $\mathrm{C}$ a promising marker of renal function, at birth, in neonates prenatally diagnosed with congenital kidney anomalies? Nephrol Dial Transplant. 2012; 27:3477-3482. [PubMed: 22474211]

26. Sarafidis K, Tsepkentzi E, Agakidou E, et al. Serum and urine acute kidney injury biomarkers in asphyxiated neonates. Pediatr Nephrol. 2012; 27:1575-1582. [PubMed: 22532328]

27. Dorum S, Silfeler I, Dorum BA, et al. Reference values of serum cystatin-C for full term and preterm neonates in Istanbul. Indian J Pediatr. 2012; 79:1037-1042. [PubMed: 22180301]

28. Lee JH, Hahn WH, Ahn J, et al. Serum cystatin C during 30 postnatal days is dependent on the postconceptional age in neonates. Pediatr Nephrol. 2013; 28:1073-1078. [PubMed: 23429977]

29. Abitbol CL, Seeherunvong W, Galarza MG, et al. Neonatal kidney size and function in preterm infants: what is a true estimate of glomerular filtration rate? J Pediatr. 2014; 164:1026-1031. [PubMed: 24607244]

30. Treiber M, Gorenjak M, Pecovnik Balon B. Serum cystatin-C as a marker of acute kidney in the newborn after perinatal hypoxia/asphyxia. Ther Apher Dial. 2014; 18:57-67. [PubMed: 24499085]

31. Randers E, Krue S, Erlandsen EJ, et al. Reference interval for serum cystatin C in children. Clin Chem. 1999; 45:1856-1858. [PubMed: 10508134]

32. Finney H, Newman DJ, Thakkar H, et al. Reference ranges for plasma cystatin $\mathrm{C}$ and creatinine measurements in premature infants, neonates, and older children. Arch Dis Child. 2000; 82:71-75. [PubMed: 10630919]

33. Montini G, Cosmo L, Amici G, et al. Plasma cystatin C values and inulin clearance in premature neonates. Pediatr Nephrol. 2001; 16:463-465. [PubMed: 11405123]

34. Armangil D, Yurdakök M, Canpolat FE, et al. Determination of reference values for plasma cystatin C and comparison with creatinine in premature infants. Pediatr Nephrol. 2008; 23:20812083. [PubMed: 18536938] 
35. Demirel G, Celik IH, Canpolat FE, et al. Reference values of serum cystatin C in very lowbirthweight premature infants. Acta Paediatr. 2013; 102:e4-e7. [PubMed: 23016830]

36. Elmas AT, Tabel Y, Elmas ON. Serum cystatin C predicts acute kidney injury in preterm neonates with respiratory distress syndrome. Pediatr Nephrol. 2013; 28:477-484. [PubMed: 23070277]

37. Elams AT, Tabel Y, Elmas ON. Reference intervals of serum cystatin C for determining cystatin C-based glomerular filtration rates in preterm neonates. J Matern Fetal Neonatal Med. 2013; 26:1474-1478. [PubMed: 23528044]

38. Treiber M, Pecovnik-Balon B, Gorenjak M. Cystatin C versus creatinine as a marker of glomerular filtration rate in the newborn. Wien Klin Wochenschr. 2006; 118:66-70. [PubMed: 16817048]

39. Maruniak-Chudek I, Owsianka-Podlesny T, Wroblewska J, et al. Is serum cystatin C a better marker of kidney function than serum creatinine in septic newborns. Postepy Hig Med Dosw. 2012; 66:175-180.

40. Ceriotti F. Establishing pediatric reference intervals: a challenging task. Clin Chem. 2012; 58:808810. [PubMed: 22377530]

41. Colantonio DA, Kyriakopoulou L, Chan MK, et al. Closing the gaps in pediatric laboratory reference intervals: a CALIPER database of 40 biochemical markers in a healthy and multiethnic population of children. Clin Chem. 2012; 58:854-868. [PubMed: 22371482] 

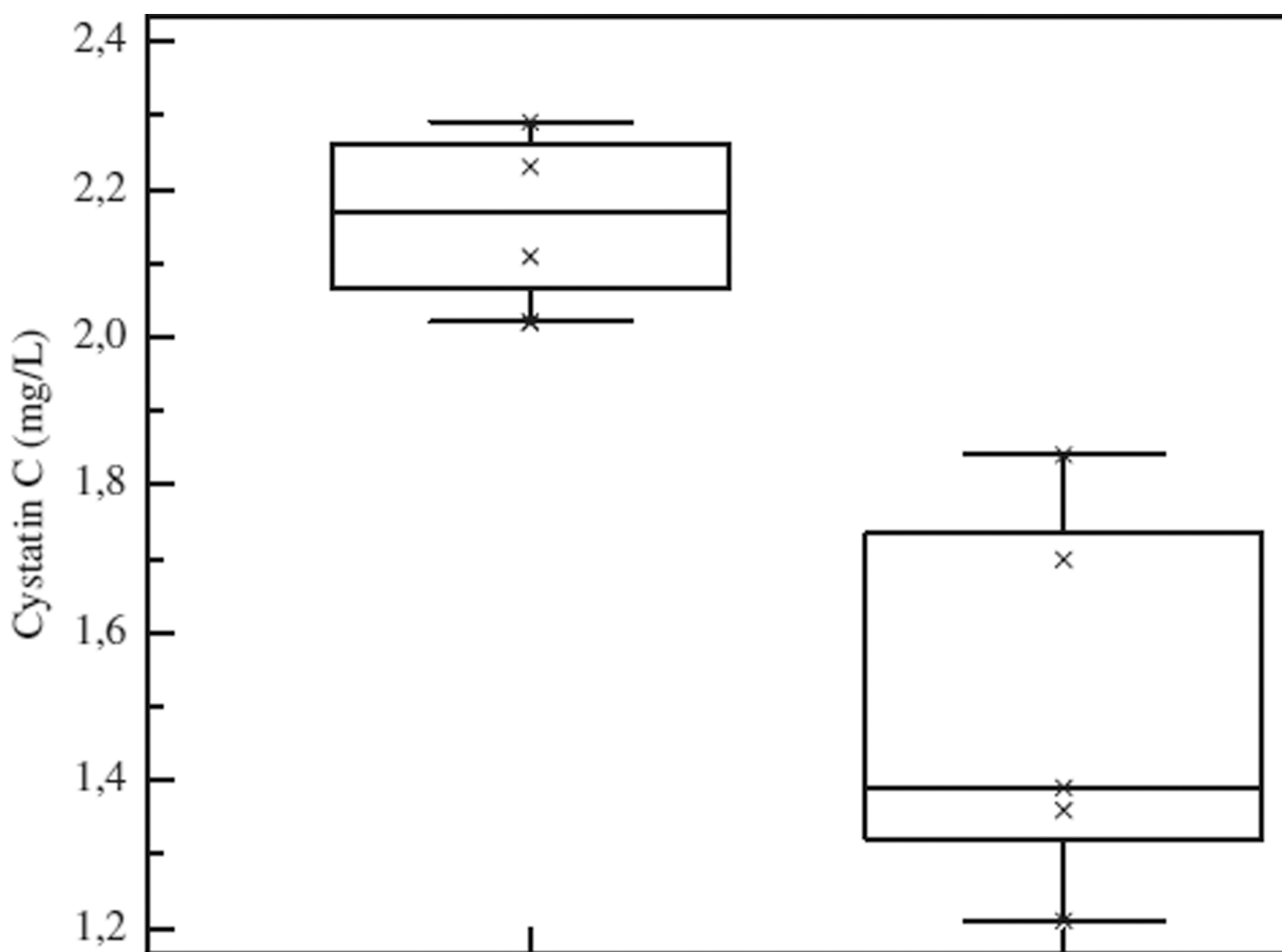

non-PENIA

\section{PENIA}

Figure 1.

Mean Cystatin C (CysC) values in 9 cohorts of healthy term newborns $(<24 \mathrm{~h})$ of life were retrieved in the literature. In 5 of these cohorts, CysC measurement was based on PENIA [21,23,27,28,30], there was one ELISA measurement [26] and 3 PETIA [16,19,20] based measurements. Mean values following PENIA were significantly lower when compared to non-PENIA techniques [PENIA = particle enhanced nephelometric immune-assay; PETIA = particle enhanced turbimetric immune-assay; ELISA = enzyme linked immune-sorbent assay]. 


\section{Table 1}

Cystatin $\mathrm{C}(\mathrm{CysC})$ reference values as reported in literature in full term healthy neonates in the first 30 days of postnatal life $($ PENIA $=$ particle enhanced nephelometric immune-assay; PETIA $=$ particle enhanced turbimetric immune-assay; ELISA = enzyme linked immune-sorbent assay, SD = standard deviation) [16,1930].

\begin{tabular}{|c|c|c|c|}
\hline Paper & Technique & Clinical characteristics & Cys C values (mg/L) \\
\hline \multirow[t]{3}{*}{ [19] } & PETIA, CysC PET kit, DAKO & Day $1, n=50$ (cord blood) & 2.23 (range 1.17-4.84) \\
\hline & & Day $3, n=50$ & 1.82 (range $0.85-3.09$ ) \\
\hline & & Day $5, n=50$ & 1.63 (range $0.66-1.63$ ) \\
\hline [20] & PETIA, CysC PET kit, DAKO & $<3$ days, $n=23$ & 2.16 (range $1.64-2.59$ ) \\
\hline [20] & PETIA, CysC PET kit, DAKO & Day $3-30, n=14$ & 2.02 (range 1.52-2.40) \\
\hline \multirow[t]{3}{*}{ [16] } & PETIA, CysC PET kit, DAKO & Day $1, n=78$ (cord blood) & $2.11(1.45-2.81)$ \\
\hline & & Day $3, n=78$ & $1.75(0.85-2.52)$ \\
\hline & & Day $5, n=78$ & $1.63(0.86-2.09)$ \\
\hline [21] & PETIA, in house & Day $1-7, n=50$ & $1.70(\mathrm{SD} 0.26)$ \\
\hline \multirow[t]{2}{*}{ [22] } & PENIA & Day $1, n=112$ & $1.36(\mathrm{SD} 0.35)$ \\
\hline & N Latex CysC, Dade Behring & Day $3, n=98$ & $1.35(\mathrm{SD} 0.33)$ \\
\hline \multirow[t]{2}{*}{ [23] } & PENIA & Day $1, \geq 36$ weeks, $n=24$ & 1.84 (range 1.32-2.63) \\
\hline & N Latex CysC, Dade Behring & Day $3, \geq 36$ weeks, $n=21$ & 1.58 (range $1.16-1.95)$ \\
\hline \multirow[t]{4}{*}{ [24] } & PENIA & Day $1, n=21$ (cord blood) & $1.70(\mathrm{SD} 0.26)$ \\
\hline & N Latex CysC, Dade Behring & Day $3, n=21$ & $1.51(\mathrm{SD} 0.19)$ \\
\hline & & Day $7, n=21$ & $1.54(\mathrm{SD} 0.15)$ \\
\hline & & Day $28, n=21$ & $1.51(\mathrm{SD} 0.15)$ \\
\hline [25] & PENIA, DAKO Cytomation & Day $1, n=100$ (cord blood) & 2.02 (range $1.40-2.70$ ) \\
\hline \multirow[t]{3}{*}{ [26] } & ELISA & Day $1, n=22$ & 2.23 (range $1.75-2.62$ ) \\
\hline & Quantikine Human CysC & Day $3, n=22$ & 2.14 (range $1.55-2.54)$ \\
\hline & & Day $10, n=22$ & 2.48 (range $2.35-2.99$ ) \\
\hline [27] & PENIA, CysC Dade Behring & Day $1, n=33$ (cord blood) & $1.21(\mathrm{SD} 0.30)$ \\
\hline \multirow[t]{6}{*}{ [28] } & Latex agglutinin immuno-assay & Day $0-3, n=119$ & $1.64(\mathrm{SD} 0.32)$ \\
\hline & (not further defined) & Day $4-6, n=99$ & $1.42(\mathrm{SD} 0.26)$ \\
\hline & & Day $7-10, n=97$ & $1.51(\mathrm{SD} 0.23)$ \\
\hline & & Day $11-15, n=44$ & $1.55(\mathrm{SD} 0.29)$ \\
\hline & & Day $16-21, n=27$ & $1.55(\mathrm{SD} 0.34)$ \\
\hline & & Day $22-30, n=14$ & $1.56(\mathrm{SD} 0.39)$ \\
\hline \multirow[t]{2}{*}{ [29] } & PENIA & Day $3-7, n=40$ & $1.33(\mathrm{SD} 0.18)$ \\
\hline & N Latex CysC, Dade Behring & & \\
\hline \multirow[t]{2}{*}{ [30] } & PENIA & Day $1, n=50$ (cord blood) & $1.39(\mathrm{SD} 0.19)$ \\
\hline & N Latex CysC, Dade Behring & Day $3, n=50$ & $1.34(\mathrm{SD} 0.21)$ \\
\hline
\end{tabular}




\section{Table 2}

Cystatin $\mathrm{C}(\mathrm{CysC})$ reference values as reported in literature in preterm healthy neonates in the first 30 days of postnatal life.

\begin{tabular}{|c|c|c|c|}
\hline Paper & Technique & Clinical characteristics & Cys C values (mg/L) \\
\hline [31] & PENIA, CysC Dade Behring & Day $8-30, n=12$ & $1.63(\mathrm{SD} 0.26)$ \\
\hline \multirow[t]{2}{*}{ [32] } & PETIA, in house & Day $1,24-28$ weeks $(n=16)$ & 1.48 (range $0.65-3.37$ ) \\
\hline & & Day $1,29-36$ weeks $(n=14)$ & 1.65 (range $0.62-4.42$ ) \\
\hline [21] & PETIA, in house & Day $1-7,32$ (range $25-37)$ weeks $(n=58)$ & $1.88(\mathrm{SD} 0.36)$ \\
\hline [33] & PETIA, CysC PET kit, DAKO & Day 4-7, 33 (range $28-34$ ) weeks $(n=20)$ & 1.88 (range $1.20-2.30)$ \\
\hline \multirow[t]{2}{*}{ [34] } & PENIA, CysC Dade Behring & Day $1,32.5$ (SD 2.6) weeks ( $n=108$, cord blood) & $1.8(\mathrm{SD} 0.30)$ \\
\hline & & Day 3, 32.5 (SD 2.6) weeks, $(n=108)$ & $1.65(\mathrm{SD} 0.30)$ \\
\hline \multirow[t]{6}{*}{ [23] } & PENIA & Day $1,24-28$ weeks $(n=22)$ & 1.63 (range $1.17-2.24$ ) \\
\hline & N Latex CysC & Day 3, 24-28 weeks $(n=23)$ & 1.47 (range 1.14-2.08) \\
\hline & & Day $1,28-32$ weeks $(n=33)$ & 1.79 (range $1.05-2.41)$ \\
\hline & & Day 3, 28-32 weeks $(n=33)$ & 1.60 (range $1.07-2.17$ ) \\
\hline & & Day $1,32-36$ weeks $(n=29)$ & 1.89 (range $0.58-2.93$ ) \\
\hline & & Day 3, 32-36 weeks $(n=37)$ & 1.64 (range $1.17-2.19$ ) \\
\hline \multirow[t]{2}{*}{ [27] } & PENIA, N Latex CysC, Dade Behring & Day $1,33-36$ weeks ( $n=30$, cord blood) & $1.21(\mathrm{SD} 0.31)$ \\
\hline & & Day $1,28-32$ weeks ( $n=35$, cord blood) & $1.41(\mathrm{SD} 0.27)$ \\
\hline \multirow[t]{8}{*}{ [35] } & not defined & Day 1, 24-26 weeks $(n=17)$ & 1.80 (range $0.80-2.20$ ) \\
\hline & & Day 3, 24-26 weeks $(n=17)$ & 1.52 (range $0.54-2.00$ ) \\
\hline & & Day $1,26-28$ weeks $(n=19)$ & 1.80 (range $1.51-3.19)$ \\
\hline & & Day 3, 26-28 weeks $(n=19)$ & 1.61 (range $1.10-3.41)$ \\
\hline & & Day $1,28-30$ weeks $(n=32)$ & 1.80 (range $0.65-2.48$ ) \\
\hline & & Day 3, 28-30 weeks $(n=32)$ & $1.70($ range $0.56-2.31)$ \\
\hline & & Day $1,30-32$ weeks $(n=45)$ & 1.79 (range $0.68-2.31)$ \\
\hline & & Day 3, 30-32 weeks $(n=45)$ & 1.61 (range 0.92-2.21) \\
\hline \multirow[t]{4}{*}{ [36] } & PENIA, N Latex CysC, Dade Behring & Day 3, 27-29 weeks $(n=11)$ & $1.34(\mathrm{SD} 0.10)$ \\
\hline & & Day 30, 27-29 weeks $(n=11)$ & $1.32(\mathrm{SD} 0.20)$ \\
\hline & & Day 3, 30-32 weeks $(n=23)$ & $1.28(\mathrm{SD} 0.20)$ \\
\hline & & Day $30,30-32$ weeks $(n=23)$ & 1.27 (range $0.68-1.58$ ) \\
\hline \multirow[t]{6}{*}{ [37] } & PENIA, N Latex CysC, Dade Behring & Day 3, 28-29 weeks $(n=11)$ & $1.34(\mathrm{SD} 0.1)$ \\
\hline & & Day 3, 30-32 weeks $(n=23)$ & $1.28(\mathrm{SD} 0.2)$ \\
\hline & & Day 3, 33-34 weeks $(n=18)$ & $1.24(\mathrm{SD} 0.2)$ \\
\hline & & Day 30, 28-29 weeks $(n=11)$ & $1.32(\mathrm{SD} 0.2)$ \\
\hline & & Day $30,30-32$ weeks $(n=23)$ & $1.25(\mathrm{SD} 0.1)$ \\
\hline & & Day $30,33-34$ weeks $(n=18)$ & $1.22(\mathrm{SD} 0.2)$ \\
\hline \multirow[t]{5}{*}{ [28] } & Latex agglutinin immuno-assay & Day $0-3, \preceq 28$ weeks $(n=15)$ & $1.60(\mathrm{SD} 0.21)$ \\
\hline & not further defined & Day 0-3, 29-32 weeks $(n=40)$ & $1.56(\mathrm{SD} 0.28)$ \\
\hline & & Day 0-3, 33-36 weeks $(n=72)$ & $1.67(\mathrm{SD} 0.25)$ \\
\hline & & Day 4-6, 28 weeks $(n=12)$ & $1.55(\mathrm{SD} 0.28)$ \\
\hline & & Day 4-6, 29-32 weeks $(n=21)$ & $1.53(\mathrm{SD} 0.21)$ \\
\hline
\end{tabular}




\begin{tabular}{|c|c|c|c|}
\hline Paper & Technique & Clinical characteristics & Cys C values (mg/L) \\
\hline & & Day 4-6, 33-36 weeks $(n=46)$ & $1.68(\mathrm{SD} 0.27)$ \\
\hline & & Day $7-10$, s 8 weeks $(n=11)$ & $1.73(\mathrm{SD} 0.41)$ \\
\hline & & Day 7-10, 29-32 weeks $(n=30)$ & $1.75(\mathrm{SD} 0.29)$ \\
\hline & & Day 7-10, 33-36 weeks $(n=61)$ & $1.69(\mathrm{SD} 0.32)$ \\
\hline & & Day $11-15, \underline{2} 8$ weeks $(n=14)$ & $1.87(\mathrm{SD} 0.26)$ \\
\hline & & Day $11-15,29-32$ weeks $(n=22)$ & $1.87(\mathrm{SD} 0.31)$ \\
\hline & & Day $11-15,33-36$ weeks $(n=25)$ & $1.72(\mathrm{SD} 0.24)$ \\
\hline & & Day $16-21, \underline{2} 8$ weeks $(n=8)$ & $1.80(\mathrm{SD} 0.28)$ \\
\hline & & Day 16-21, 29-32 weeks $(n=26)$ & $1.68(\mathrm{SD} 0.31)$ \\
\hline & & Day 16-21, 33-36 weeks $(n=26)$ & $1.81(\mathrm{SD} 0.22)$ \\
\hline & & Day $22-30, ~ s 28$ weeks $(n=11)$ & $2.02(\mathrm{SD} 0.42)$ \\
\hline & & Day 22-30, 29-32 weeks $(n=23)$ & $1.84(\mathrm{SD} 0.27)$ \\
\hline & & Day 22-30, 33-36 weeks $(n=20)$ & $1.64(\mathrm{SD} 0.23)$ \\
\hline [29] & PENIA, N-latex CysC Dade-Behring & Day 3-7, $34(\mathrm{SD} 3)$ weeks $(n=60)$ & $1.42(\mathrm{SD} 0.21)$ \\
\hline
\end{tabular}

PENIA = particle enhanced nephelometric immune-assay; PETIA = particle enhanced turbimetric immune-assay; ELISA = enzyme linked immune-sorbent assay, $\mathrm{SD}=$ standard deviation $[24,28,30,32-37]$. 


\section{Table 3}

Plasma cystatin $\mathrm{C}(\mathrm{Cys})$ values in neonates with specific perinatal disease characteristics.

\begin{tabular}{|c|c|c|c|}
\hline Reference & Assay & Clinical characteristics & CysC values \\
\hline \multirow[t]{3}{*}{ [33] } & PETIA & Preterms $(n=20)$, Postnatal 4-7 days & $1.88(1.2-2.3) \mathrm{mg} / \mathrm{L}$ \\
\hline & & 28-34 weeks, birth weight 910-2250 g & \\
\hline & & Raised $\mathrm{Cys} C$ in cases with lower inulin clearance & \\
\hline \multirow[t]{3}{*}{ [38] } & PENIA & $n=75$, umbilical blood at birth (34-41 weeks) & $1.97(\mathrm{SD} 0.60) \mathrm{mg} / \mathrm{l}$ \\
\hline & & Raised CysC with pH57.2 at birth & \\
\hline & & Correlation $(r=0.28)$ with hemoglobin & \\
\hline \multirow[t]{2}{*}{ [25] } & PENIA & 100 controls (term), all umbilical cord blood & $2.02(1.54-2.64) \mathrm{mg} / \mathrm{l}$ \\
\hline & & 13 congenital renal anomaly cases, bilateral & $2.52(1.80-3.50)(+24.5 \%) \mathrm{mg} / \mathrm{l}$ \\
\hline \multirow[t]{4}{*}{ [39] } & ELISA & 32 neonates, $34-40$ weeks, 0 and $48 \mathrm{~h}$ & \\
\hline & & Sepsis & $1.47(1.01-1.9)$ to $1.43(1.05-1.81) \mathrm{mg} / \mathrm{l}$ \\
\hline & & Severe sepsis & $1.5(1.12-1.87)$ to $1.31(1.05-1.58) \mathrm{mg} / \mathrm{l}$ \\
\hline & & Septic shock & $1.23(0.92-1.54)$ to $1.21(0.95-1.47) \mathrm{mg} / \mathrm{l}$ \\
\hline \multirow[t]{8}{*}{ [36] } & PENIA & 34 cases without respiratory distress, day 3 & $1.30(\mathrm{SD} 0.2) \mathrm{mg} / \mathrm{l}$ \\
\hline & & 28 cases with respiratory distress, day 3 & \\
\hline & & No acute kidney injury $(22 / 28)$ & $1.14(\mathrm{SD} 0.1) \mathrm{mg} / \mathrm{l}$ \\
\hline & & Acute kidney injury $(6 / 28)$ & $1.49(\mathrm{SD} 0.09) \mathrm{mg} / \mathrm{l}$ \\
\hline & & 34 cases without respiratory distress, day 30 & $1.29(0.68-1.67) \mathrm{mg} / \mathrm{l}$ \\
\hline & & 28 cases with respiratory distress, day 30 & \\
\hline & & No acute kidney injury $(22 / 28)$ & $1.40(1.01-1.89) \mathrm{mg} / \mathrm{l}$ \\
\hline & & Acute kidney injury (6/28) & $1.51(1.16-1.70) \mathrm{mg} / \mathrm{l}$ \\
\hline \multirow[t]{3}{*}{ [29] } & PENIA & Preterm, 34 (SD 3) weeks & 1.35 (SD 0.19$)$ to $1.47(\mathrm{SD} 0.21) \mathrm{mg} / \mathrm{l}$ \\
\hline & & Second part of first week of life & \\
\hline & & $26 / 60$ exposed to gentamicin (CysC lower) & \\
\hline \multirow[t]{3}{*}{ [30] } & PENIA & 50 term cases perinatal asphyxia/controls & \\
\hline & & At birth (umbilical cord blood) & $2.12(\mathrm{SD} 0.53)$ to $1.39(\mathrm{SD} 0.19) \mathrm{mg} / \mathrm{l}$ \\
\hline & & On day 3 of life (venous blood) & $1.56(\mathrm{SD} 0.32)$ to $1.34(\mathrm{SD} 0.21) \mathrm{mg} / \mathrm{l}$ \\
\hline
\end{tabular}

PENIA = particle-enhanced nephelometric immune-assay; PETIA = particle-enhanced turbimetric immune-assay; ELISA = enzyme linked immune-sorbent assay, $\mathrm{SD}=$ standard deviation $[25,29,30,33,36,38,39]$. 